\title{
THE CONTENT OF PRIMARY SCHOOL TEACHERS' TRAINING IN THE CONTEXT OF PROVIDING INFORMATION AND COMMUNICATION TECHNOLOGIES INTO THE INCLUSIVE EDUCATIONAL ENVIRONMENT
}

\section{S. Chupakhina}

В статті проаналізовано особливості підготовка майбутніх учителів початкової школи до роботи $з$ комп'ютером як засобом управління інформацією, а також з інформацією в глобальних комп'ютерних мережах, й володіння цифровими компетентностями задля проектувати $і$ застосовувати інформаційних технологій, основу яких складають електронні освітні ресурси.

Розглянуто та обгрунтовано основні напрямки вдосконалення підготовки майбутніх учителів початкової школи до застосування інформаиійно-комунікативних технологій у професійній діяльності в умовах інклюзивного освітнього середовища.

Мета статmі. Аналіз стану та обтрунтування напрямків підготовки майбутніх учителів щзодо особливостей та можливостей використання інформаційно-комунікаційних технологій в інклюзивному освітньому середовищі початкової школи.

Водночас охарактеризовано особливості функціонування інформаційно-освітнього інклюзивного середовища, яке передбачає інформаційну взаємодію між користувачами (педагогами, фахівиями, батьками, учнями та ін.).

Запропоновано програму навчальної дисципліни «Інформаційні технології в інклюзивній освіті дітей $з$ ускладненнями процесів розвитку та сочіалізації».

Доведено, щз пропоновані методичні принципи та напрями вдосконалення змісту підготовки майбутніх учителів до використання інформаційних технологій у професійній діяльності в умовах інклюзивного освітнього середовища передбачають певну практико зорієнтовану організацію роботи. Реалізацію програми підготовки, в межах спеціально організованого курсу, зосередженого на вдосконаленні знань $i$ умінь щцодо застосування означених технологій у професійній діяльності в умовах інклюзивного середовища. Відтак учитель в інформаційному суспільстві як кваліфікований працівник інтелектуальної праці, з високим рівнем освіти, стає головним ресурсом підвищення ї̈ якості, щцо сприятиме формуванню демотиваційних індикаторів серед учасників освітнього процесу щуодо трудової міграції

Ключові слова: інформатизачія, інклюзивне освітнє середовище, електронні освітні ресурси, компетентність, підготовка майбутніх учителів

\section{Introduction}

Rapid changes in the technological development, continuous growth of information and improvement of cognition forms, reflected in all spheres of human activity, certainly affect the education process. Informatization of education is becoming one of the main directions in the modern information society.

Informatization is becoming a process, focused on the introduction of information and communication technologies (ICT) into education. It encourages the improvement of the quality of education.

The introduction of information technologies (IT) in education helps to solve problems of developing a positive learning motivation for students, opens up fundamentally new opportunities for management of educational and cognitive activity, increases the efficiency of educational work and ensures the effectiveness of the learning process as a whole.

\section{Literature review}

Taking into account the results of current researches, electronic educational resources provide us with the opportunity to organize cognitive activities of pupils rationally; help make learning more effective; to build an open system of education, providing individualization of learning; to involve in the process of active learning the children who differ in their abilities and styles of learning; to turn to fundamentally new cognitive tools; to intensify all levels of the educational process [1].

Modern education considers the information (IT) competence of a teacher as one of the most vital components of his/her professional activity, which provides qualitative characteristics of pupils' knowledge. In institutions of higher education (IHE) the implementation of the educational program is focused on pedagogical technologies. At the same time, the requirements for the qualification of primary school teachers, in accordance with the professional standard of teacher training, include characteristics of professional skills in the field of information and communication competence and willingness to use electronic educational resources in the educational process [2].

Training future primary school teachers, the focus is on the fact that the modern educator should not only be ready to work with computers as a means of managing 
information, but also to work with information in global computer networks, and to have ICT competencies, be able to design and apply ICT resources, based on elearning resources.

The scientists have suggested the "Complex of computer information technologies to support inclusive education of children with special needs", it consists of three components: computer simulator of Ukrainian Sign Language, distributed web-based environment of distance learning, tools for creating audio textbooks [1]. The focus is on creating the information base for audio materials and teaching aids for educating blind users, pupils and students.

At the global level a specialized ICT course in educating people with disabilities has been developed. It offers IT tools for inclusive education, as well as tools for computer-based training [3].

In accordance with the system approach, which is implemented by modern educational standards of higher professional education, the graduates' knowledge on information, technology as well as skills become of universal importance, that is, providing sufficient knowledge for implementation in the pedagogical practice is of current interest.

The introduction of inclusive education has led to changes in the professional training of teachers for pedagogical interaction with children with special educational needs, and at the same time, it calls for urgent changes in systematic vocational training of future teachers to work with children with special needs in inclusive education.

Let us consider in details scientific approaches to shaping the future teachers' readiness for the professional practice in the inclusive educational environment. A number of components of readiness to work are distinguished in scientific researches: professional and psychological; cognitive, motivational, reflexive and operational; missionary, competent and self-regulating; motivational-personal, cognitive-operative and reflexiveevaluative; professional-personal, theoretical-cognitive and practical-activity; motivational, theoretical and operational; psychological and professional; cognitive, emotional and connotative [4].

At the same time, author's models of professional training of future teachers to work under conditions of inclusive educational institutions have been suggested $[5,6]$.

At the same time, the importance of the informational competence of teachers under conditions of communication technologies introduction in the educational space of schools is increasing. Qualitative application for information technologies in the educational process depends on quality of teacher training, consequently, the future of the society depends on it as well [1]. Psychological and pedagogical aspects of IT introduction in the educational process have become vital for our research $[3,6]$.

\section{The aim and objectives of the study}

The aim of this study is to analyze the situation and to substantiate the directions of future teachers' training to use information and communication technologies in the inclusive primary school educational environment.
To achieve the aim, the following tasks were set:

1. To consider methodological principles and directions for improving the content of future teachers' training to use ICT in the professional practice in the inclusive educational environment.

2. To substantiate educational and professional tasks of using electronic educational resources in inclusive education.

3. To offer a training program within a specially organized course focusing, on qualifying the competence of using ICT in practice.

\section{Theoretical and methodological aspects of future teachers' training to use ICT in the inclusive educational environment}

Taking into account the importance of our research, the results of which allowed us to determine theoretical, organizational and methodological aspects of providing information and communication technologies in the future teachers' training process, it is necessary to note the lack of systematic development of pedagogical support for informatization in the inclusive educational process. The content and organization of students' training to use e-educational resources (EER) in the inclusive educational environment remain insufficiently studied, and the psychological and pedagogical aspects of the process of forming a positive motivation for mastering the necessary competencies for the use of EER in inclusive teaching of children with intellectual disabilities are required.

At the initial stage of our research, we will consider more thoroughly the main directions of improving future primary school teachers' training (PS) to apply ICT in their professional practice.

In our opinion, the first direction of the training content is provided by the main features of the modern information society, the globalization of network communication. It reveals its impact on the education development in the context of informatization. It is also important to justify ICT opportunities and their importance for improving modern education $[5,7]$.

The concept of "information society" needs substantiating. It considers the content and features of the modern society in the context of information, network communication and globalization, which initiates the use of ICT in all types of educational, scientific, industrial, and professional, leisure and everyday activities. The concept of "informatization of the society" is defined as a socio-economic process that covers all spheres of the modern society where information activity in information interaction becomes the most common type of life for most individuals [7].

Let us consider the essence of the concept "informatization of education" (Fig. 1).

This direction covers the definition of ICT tools, information interaction, information processes and shows their importance in the development of education. This includes explanations of organizational forms and activities for the collection, processing, storage, transmission, display and production of information and information interaction among the subjects of the educational process 
(users of education and interactive information tools vs. educational systems, operating on the basis of ICT) [1].

Information interaction with the use of ICT implies the process of information exchange, which is reflected in the form of text, graphics, animation, audio, video, during its transmission and reception, implementation of feedback (interactive dialogue), during the collec- tion, processing, transmission, archiving and production of information. The structure of information interaction is considered as an internal form of organization of information interaction between a teacher, a pupil and an interactive source of information that realizes didactic possibilities of ICT under the condition of feedback between them [5].

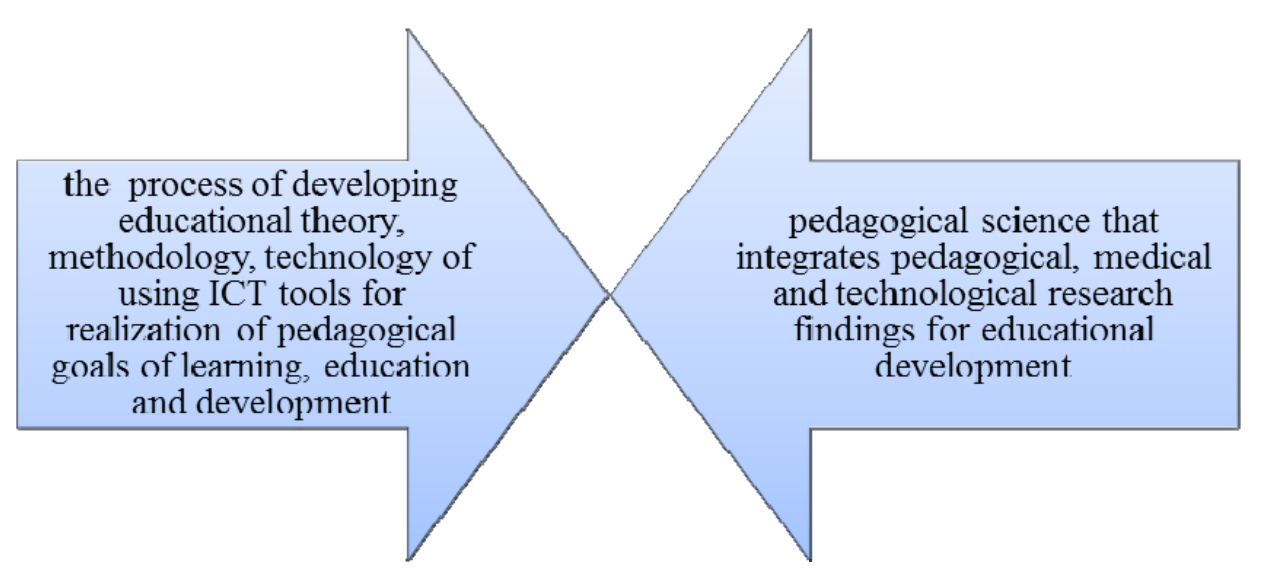

Fig. 1. The essence of the concept "education informatization". Created by the author by [7]

According to the scientists, the didactic capabilities of ICT include "feedback, which determines the implementation of interactive dialogue, which is characterized by the fact that each request of the student is displayed by the relevant information on the screen, which requires the actions of the seeker; visualization on the screen of educational information about the studied objects, processes, their graphical display; storage of a great amount of information and easy access to it, transfer, duplication; automation of information activity on collec- tion, processing, transfer, display, duplication of information, archival storage of all information with the possibility of easy access to it and access to the user; automation of processes of information and methodological support, organizational management of educational activity and monitoring of results of mastering knowledge"'[1].

The important aspect of the process is the pedagogical feasibility of using ICT in the teaching practice (Fig. 2).

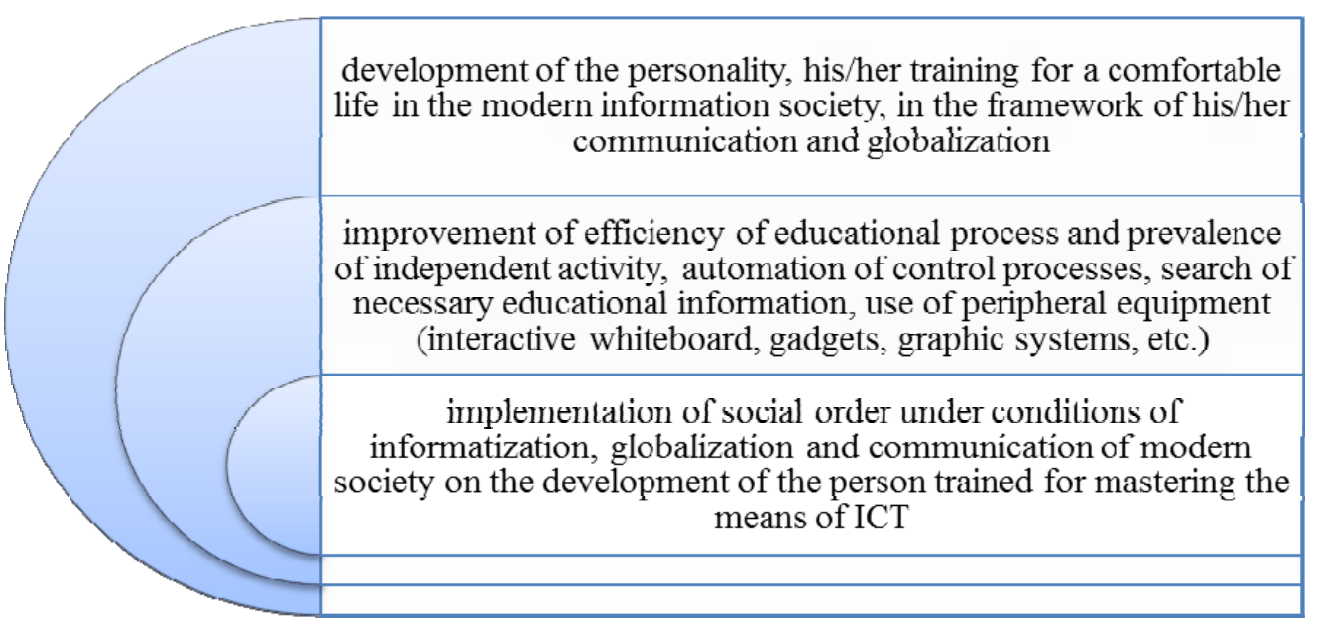

Fig. 2. Pedagogical feasibility of using ICT. Created by the author by [5]

Substantiating the causes of possible negative consequences of pedagogical nature (namely wrong information, poor structuring, quality and content, taking into account the age characteristics and abilities of the pupils' perception and their level of development) and of medical nature (long "virtual communication" in social networks; playing computer games in a virtual reality, constant networking in particular, when chatting; the absence of comfortable, ergonomic design of workspaces, equipped by ICT; a large discrepancy between color, 
sound, visual presentation of information on the screen and WHO recommendations) [6]. All these may arise in working with ICT tools, generated by the risks and challenges of the information society, and measures to prevent them $[7,8]$.

The second direction reveals the opportunities of the primary school information and educational environment.

We suggest creating the educational environment for primary school as a set of conditions, in order to facilitate the emergence and development of processes of educational information interaction between pupils, teacher and information educational resources by means of interactive ICT. In this situation it is worth describing the objects of primary education and educational environment: software, hardware and information systems, information networks; educational and methodological developments and organizational materials of the education system, which are presented electronically, educational information resources or electronic offices for inclusive learning [7, 9].

At the same time, the functioning of the information and educational inclusive environment (IEIE) involves informational interaction among users, among educators and between educators and parents, educators and pupils.

Of course, the structure of the IEIE of primary school envisages the structure of components that implement the conditions of informational-educational interaction between pupils, teachers and the informational educational resource by means of ICT. Mentioned above directions of information flows from teacher to teacher, to pupils, to parents (in direct and feedback), and also an interactive information resource (in direct and feedback). The components of the information-learning interaction are the subjects of the educational process and the interactive means of ICT (or interactive information resource (IIR). The structure of information interaction (direct and feedback) between all participants (teacher, pupil (pupils) and IIR) can be presented in the following way (Fig. 3).

The third direction reveals the content aspects of EER in the inclusive educational environment and its educational and methodological support [9].

IIIR is defined as an information system of the educational complex purpose, which realizes didactic possibilities of ICT through software (without access to paper media) at all stages of education: setting a task, presenting the content of educational and methodical material (with possible searching for information on the Internet), the organization of activities to perform individual tasks, feedback between the subjects of the educational process, automation of pupil activity control $[7,9]$.

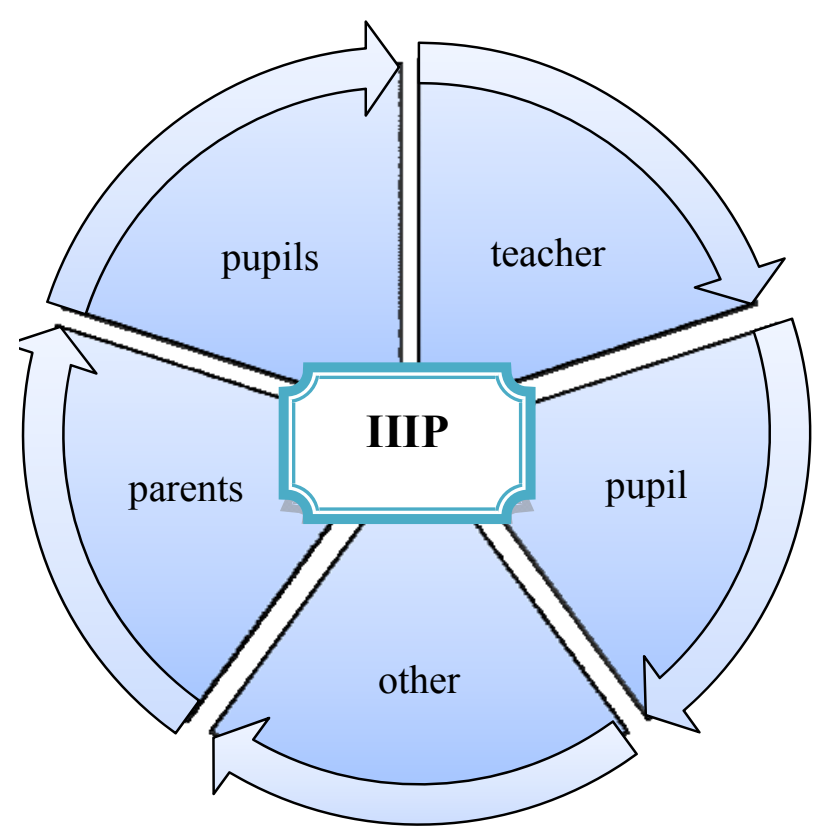

Fig. 3. Structure of information interaction within the framework of interactive information inclusive resource (IIIR). Created by the author

The fourth direction provides theoretical and methodological aspects of information security of primary school pupils under conditions of the modern information society and mass network communication $[7,8]$.

Therefore, let us look at a number of aspects of personal information security (Fig. 4).

The fifth direction reflects organization of online professional communities of primary school teachers in order to realize their opportunities in the professional practice and to exchange experience of using ICT in the context of IEIE [7]. 


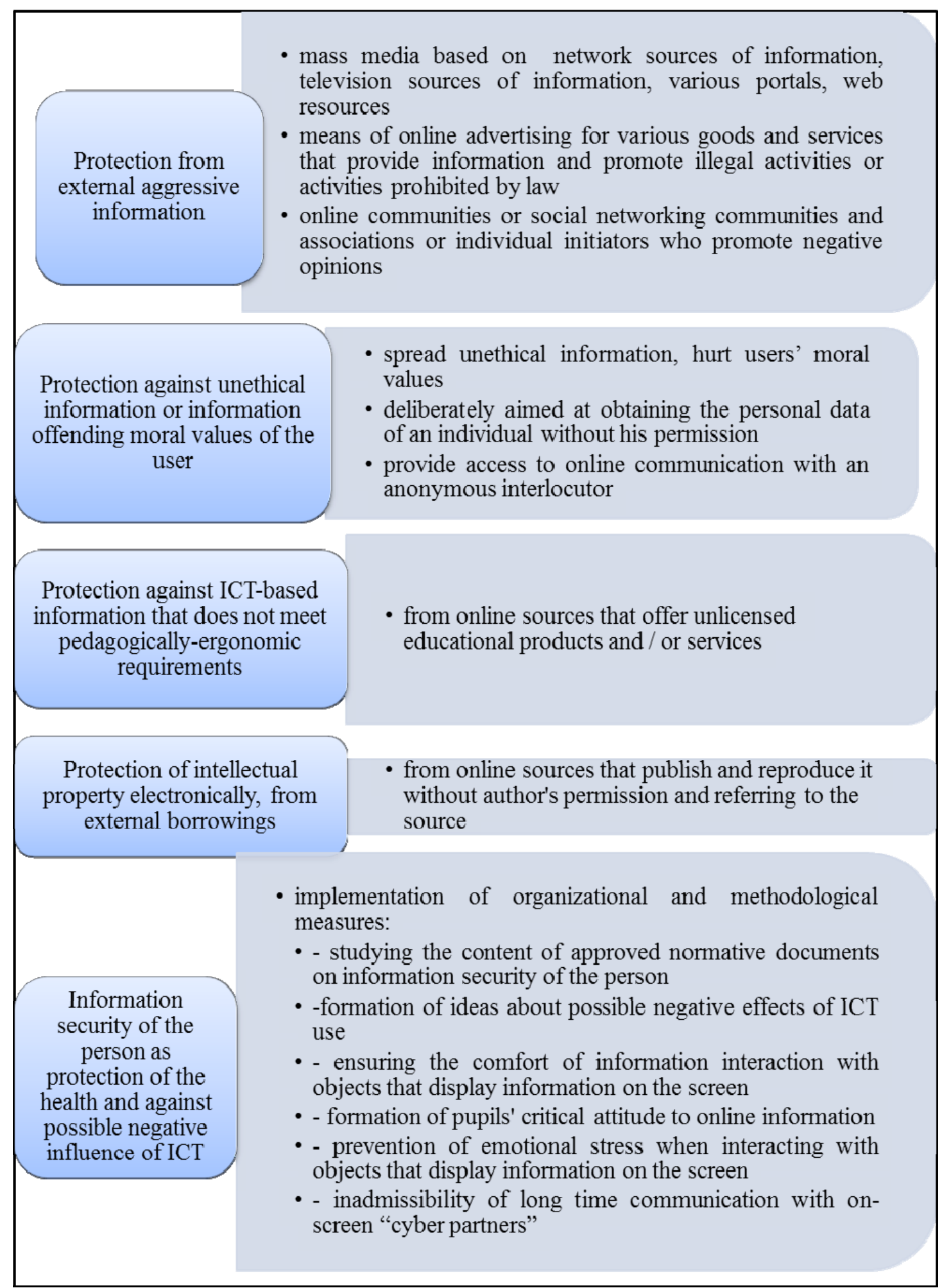

Fig. 4. Ensuring information security of an individual. Created by the author by $[8,9]$

The suggested direction is focused on training future teachers to use ICT in the context of IEIE.

1. The pedagogical expediency of using social networks in inclusive education is revealed:

- social network as an object of study for information gathering (reports, research results, coursework, reports, etc.);

- social networks for the implementation of educational programs for joint development by teachers, who are located in remote areas, educational and meth- odological developments, educational activities, IIR and others;

- informational interaction of teachers in social networks pursue the following goals: publication, discussion and expert evaluation of author's development programs, identification of the best ones; replication of the best educational and methodological developments in electronic form, to users of the social network; conducting "open web-lessons" with further discussion by their social network users; IIIR expertise with recommenda- 
tions for the users of the social network on how to collect and prepare them.

2. The organization of various forms of informational interaction is becoming of great importance. It can be between teachers, pupils and their parents, pupils, teachers, authority of educational institutions and within the created educational community in the social network when creating diverse network communities (by topic, discipline, news, sphere for joint development of plans, reports, teaching materials, submitted electronically, for duplication of author's developments and links to other online resources, for study other people's thoughts on published topics) [10].

3 . There are various ways of organizing educational activities in social networks and their use in the educational process:

- organization of a thematic site, which is created on the Internet for future employment, creation of thematic pages for the organization of various educational activities:

- organization of joint independent work of students for discussion of educational materials, realization of creative projects;

- analyzing, comparing and collating opinions from disciplines, discussing, formulating analytical conclusions, to use them in the coursework, reports, etc. (on condition that you are subscribed to social media pages on a specific topic);

- information search and selection (obtaining) of scientific and educational information for discussing student tasks and carrying out research projects and their informational support (books, electronic database addresses), activities of students within the social network community for information retrieval;

- posting students' texts (report, coursework, queries, opinions, etc.) on their own social networking pages in order to discuss the work together, to ask colleagues to discuss and write job offers, and to evaluate work completed.

\section{Research results}

Taking into account all mentioned above, we suggest the program of the discipline "Information Technologies in Inclusive Education of Children with Development and Socialization Problems".

1. The peculiarities of the modern information society of global mass network communication, its influence on education.

1.1. The essence of the concepts "information society", "informatization of education", "means of ICT", "information interaction by means of ICT".

1.2. Forms and methods of information activities and information interaction, implemented by ICT, between pupils and interactive information resources of the educational purpose.

1.3. Didactic possibilities of information and communication technologies and pedagogical expediency of using ICT tools.

1.4. The reasons for the possible negative consequences of the pedagogical and medical nature of the use of ICT tools.

1.5. Practical training.
(1.5) Application of "MS Office software package" for planning, analysis and control of the educational activity in inclusive education of children with intellectual disabilities (surveys, testing, storing information about pupils, keeping a database of subjects).

(1.5) Creating control materials, based on "MS Excel spreadsheets".

(1.5.) Organizing information activities, regarding the retrieval, collection, processing, storage and transmission of training information, submitted electronically for the interaction of participants in the escort team.

(1.5.) Use of information resources (Internet resources) in the activities of primary school teachers.

(1.5.) Submission of established forms of planning, organization and control of the educational activity in accordance with a specific model in electronic form.

(1.5.) Creating methodological guidelines for the planning and organization of educational activities in the inclusive educational environment, using ICT opportunities.

2. Inclusive primary school educational environment.

2.1. Determination of the information and educational environment of PS, its composition in the context of software, hardware and information.

2.2. Structure of the informational-educational inclusive environment of PS as a system of components that realize the possibility of informational-educational interaction between pupils, teacher and information educational resource by interactive means of ICT.

2.3. Practical training.

(2.3.) Application of e-mails, school sites, "MS Office software package" for informative interaction with participants of the inclusive educational process.

(2.3.) Selection of forms of organization of educational activities, information interaction with participants of the inclusive educational process through the Internet.

(2.3.) Development and creation of web-pages, web-sites, personal thematic sites of the teacher for activity organization under conditions of the inclusive educational environment.

(2.3.) Creating various forms of information interaction between participants, pupils and their parents, school authority within the social network.

(2.3.) Use of online resources for lessons in the inclusive classroom.

(2.3.) Informational interaction with the participants of the educational process within the online network in order to optimize the educational activity.

(2.3.) Using a variety of teaching materials, posted on schools' websites.

(2.3.) Adaptation and improvement of information and methodological materials, presented in electronic form, taken from the Internet.

3. Educational and methodical aspects of information technologies in education of children with development and socialization problems.

3.1. Computer technology in the theory and practice of special and inclusive learning.

3.2. Forms and methods of working with pupils with development and socialization problems by means of ICT. 
3.3. Training primary school pupils with development and socialization problems to work with PC software (the basics of computer literacy).

3.4. Practical training.

(3.4.) Information technology in educating children with development and socialization problems (mathematics training).

(3.4.) Use of IT to store students' observation results of the learning process.

(3.4.) Computer games in the process of teaching mathematics to children with development and socialization problems.

(3.4.) Creating the inclusive educational information space in today's school.

4. Theoretical and applied aspects of realization of information security of primary school pupils under conditions of the modern information society.

4.1. Essence of the concept "information security of the person".

4.2. Organizational and methodological measures to protect pupils from the negative impact of ICT.

4.3. Practical training.

(4.3.) Identification of the causes of possible negative effects of ICT on the health of primary school pupils.

(4.3.) Implementation of organizational and methodological measures to protect the health of pupils with problems from the possible negative impact of ICT.

(4.3.) Development and implementation of organizational and methodological measures for ensuring information security of the pupils in the conditions of using ICT tools.

(4.3.) Use of online educational resources that meet the information security requirements of the person.

(4.3.) Use of ICT in the context of organizational and methodological measures to ensure the health of the pupil.

5. Organization of online communities of primary school teachers for the implementation of the tasks of information education.

5.1. Pedagogical feasibility of using social networks in the inclusive educational environment (social network as an object of study, social networks for the implementation of educational programs, for informational interaction of teachers in social networks).

5.2. Formation of various forms of informational interaction between teachers, pupils and their parents, students, teachers within the created educational community in the social network.

5.3. Organizing educational activities in social networks and applying them in the educational process of institutions of higher education.

5.4. Practical training.

(5.4.) Search and selection of educational and methodological materials in social networks for improvement of the inclusive educational process.

(5.4.) Organization of the educational process, applying to social networks.

(5.4.) Use of various forms of informational interaction between teachers, pupils and their parents, school authority within the social network.
(5.4.) Selection and placement of educational materials and special educational programs on social networks.

(5.4) Organizing teachers' activity on social networks to improve inclusive learning.

The introduction of the given academic discipline into the educational process of higher educational institutions makes it possible to solve a number of problems regarding future teachers' readiness to work in modern primary school as a specialist. Improving professional training and solving a number of professional problems through the creation of IEIE will help to meet professional needs, connected with flexibility and variability, at the same time it will ensure the continuous access to selfeducation and self-development. The suggested approach proves its urgency and provides:

- structuring of the information inclusive environment of an educational institution;

- systematic informational support for the management of the inclusive educational process in practice;

- organizing high-level education for participants in the educational process and maintain this interest in lifelong learning.

At the same time, the transition to education in a new technological era enhances the role of knowledge and professional skills. Economics of knowledge is being formed, which is rightly regarded as a new mechanism of the socio-economic development of the state. Therefore, a teacher as a skilled and intelligent worker, who is highly educated, becomes a major resource for improving her / his quality; it will contribute to the formation of demotivating indicators among the participants of the educational process on labor migration.

\section{Conclusions}

Summarizing all the information, mentioned above, we can conclude:

1. The suggested methodological principles and directions for improving the content of future teachers' training for using ICT in practice in the context of IEIE provide a certain practice-oriented organization of work.

2. Implementation of the training program within a specially organized course, focused on improving the knowledge and skills in the use of ICT in practice in the context of IEIE, taking into account the current achievements of informatization of education, requires the assessment of the formation of appropriate levels of the competence, that is, the involvement of a competent approach.

3. The process of training future primary school teachers solves educational and professional tasks using EER in inclusive education:

- assisting a student in solving typical tasks and mastering the algorithm of selection and use of ICT in practical work with children with intellectual problems;

- orienting students to see problems of a lesson in an inclusive classroom and search for electronic resources to solve this problem; finding out the peculiarities of the topic under study by students and selecting electronic educational resources to solve it;

- encouraging the students to search for opportunities of electronic educational resources and apply them when preparing for lessons in an inclusive class. 


\section{References}

1. Demchenko I. I. Teoretychni i metodychni zasady pidhotovky maibutnoho vchytelia pochatkovykh klasiv do profesiinoi diialnosti v umovakh inkliuzyvnoi osvity: Doctors of Pedagogical Thesis. Uman, 2016. 716 p.

2. Myronova S. P. Realii ta perspektyvy zabezpechennia inkliuzyvnoi osvity fakhivtsiamy // Naukovyi chasopys Natsionalnoho pedahohichnoho universytetu imeni M. P. Drahomanova. Seriia 19: Korektsiina pedahohika ta spetsialna psykholohiia. 2016. Issue 32 (2). P. 5-10.

3. Sharma M. Innovative roles of guidance and counseling for managing children with learning disabilities in inclusive classroom by inclusive teachers // International Journal of Research in Social Sciences. 2016. Vol. 6 Issue 12. URL: https://www.academia.edu/35974967/Innovative_Roles_of_Guidance_and_Counseling_for_Managing_Children_with_Learning_Dis abilities_in_Inclusive_Classroom_by_Inclusive_Teachers

4. Leniv Z. Formuvannia profesiinoi hotovnosti fakhivtsia do roboty $\mathrm{v}$ inkliuzyvnomu osvitnomu prostori pochatkovoi shkoly // Obrii. 2018. Issue 2 (47). S. 57-61

5. Kachurovska O. B. Do problemy vykorystannia informatsiino-komunikatsiinykh tekhnolohii v navchanni ditei z osoblyvymy osvitnimy potrebamy // Naukovyi chasopys Natsionalnoho pedahohichnoho universytetu imeni M. P. Drahomanova. Seriia 19: Korektsiina pedahohika ta spetsialna psykholohiia. 2014. Issue 27. P. 71-75. URL: http://nbuv.gov.ua/UJRN/Nchnpu_019_2014_27_17

6. Shevtsiv Z. M. Profesiina pidhotovka maibutnikh uchyteliv pochatkovoi shkoly do roboty v inkliuzyvnomu seredovyshchi zahalnoosvitnoho navchalnoho zakladu: monograph. Kyiv: «Tsentr uchbovoi literatury», 2017. 384 p.

7. Zaporozhchenko Yu. H. Vykorystannia zasobiv IKT dlia pidvyshchennia yakosti inkliuzyvnoi osvity // Informatsiini tekhnolohii v osviti. 2013. Issue 15. P. 138-145. URL: http://nbuv.gov.ua/UJRN/itvo_2013_15_17

8. Chupakhina S. Methodological bases for digital competence formation of future teachers under conditions of inclusive education: Ukrainian content / ed. by Babych M. M. // Modern World tendencies in the development of science: monograph. Vol. 2. London: Sciemcee Publishing, 2019. P. 26-40.

9. Fedorenko I. V. Cuchasni pidkhody do vykorystannia kompiuternykh tekhnolohii u navchalnomu protsesi uchniv zriznymy porushenniamy psykhofizychnoho rozvytku // Zbirnyk naukovykh prats Kamianets-Podilskoho natsionalnoho universytetu imeni Ivana Ohiienka. Seriia: Sotsialno-pedahohichna. 2012. Issue 19 (1). P. 268-274. URL: http://nbuv.gov.ua/UJRN/znpkp_sp_2012_19(1)_31

10. Sofii N. Z. Orhanizatsiino-pedahohichni umovy intehrovanoho suprovodu uchniv z osoblyvymy osvitnimy potrebamy v inkliuzyvnomu navchalnomu zakladi: abstract $\mathrm{PhD}$ thesis. Kyiv, 2017. 23 p.

Received date 15.01.2020

Accepted date 06.02.2020

Published date 25.05.2020

Vitlana Chupakhina, PhD, Associate Professor, Department of Theory and Methodology of Preschool and Special Education, State Higher Educational Institution "Vasyl Stefanyk Precarpathian National University", Shevchenka str., 57, Ivano-Frankivsk, Ukraine, 76018

E-mail: cvitlana2706@gmail.com 